
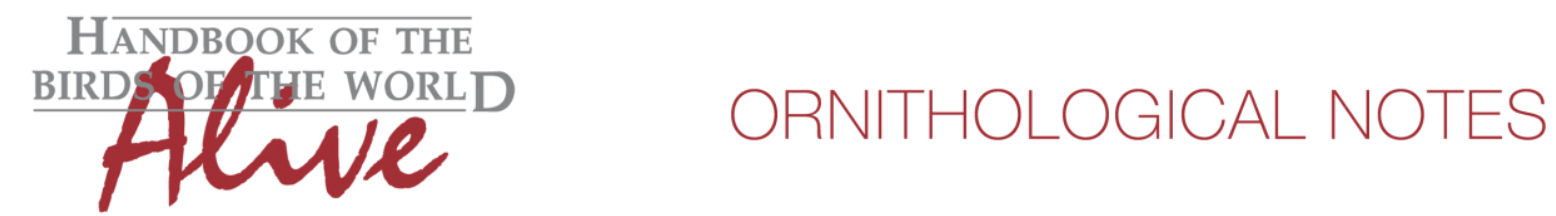

\title{
Notes on the vocalizations of Bar-winged Cinclodes (Cinclodes fuscus)
}

Peter Boesman

While taxonomy of $C$. fuscus has been studied extensively (e.g. Sanín et al. 2009), surprisingly this has never included any serious analysis of voice (even referring without further detail to 'Birds of Chile' (Jaramillo 2003) as a proof of distinct voices for the three groups, while obviously the northern group is not treated in here).

In the following we briefly analyze and compare voice of the different races of Bar-winged Cinclodes (Cinclodes fuscus). We also try to quantify the extent of any vocal differences using the criteria proposed by Tobias et al. (2010), as a support for taxonomic review. We have made use of sound recordings available on-line from Xeno Canto (XC).

\section{Chestnut-winged Cinclodes group}

Song is a rattling trill at more or less same pitch or slightly rising at end (Fig. 1). There is some variation among the races:

- oreobates: no recordings found

- heterurus: trill consists of clear short overslurred notes, at start gradually increasing in pitch and amplitude, at end rising in pitch and becoming more spaced and notes downslurred

- albidiventris (few recordings of song): trill consists of short notes which have pronounced harmonics, thus sounding more metallic rattling compared to previous race. There is no clear starting and ending part, rattle is quite uniform over its entire length.
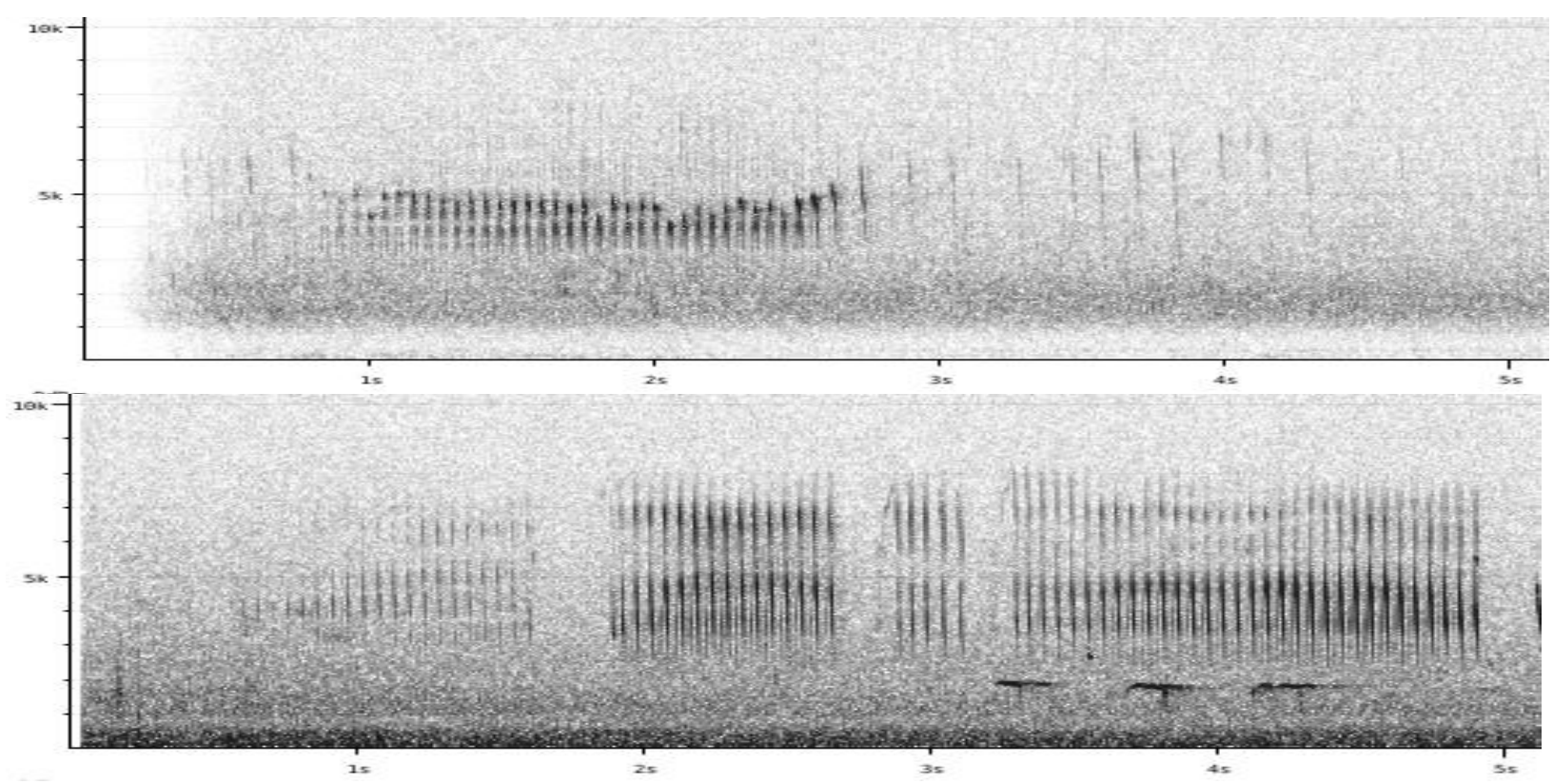

Figure 1: typical song of heterurus (top) and albidiventris (bottom) 

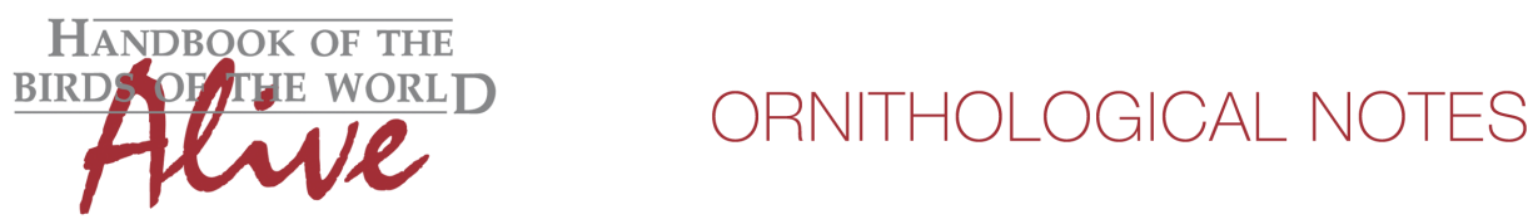

Common features among the above races:

note length in trill: $\quad 0.03-0.05 \mathrm{~s}$

pace* in trill: $\quad 0.044-0.05$

max freq of notes in trill: $\quad 5000-6000 \mathrm{~Hz}$

min freq of notes in trill: $\quad 1700-2000 \mathrm{~Hz}$

* Pace measured here as period: duration between 2 consecutive notes

\section{Cream-winged Cinclodes group}

Song is quite distinctive: a series of well-spaced very high-pitched notes dropping and switching into a lower-pitched fast rattling trill which then again rises and slows into similar very high-pitched notes (Fig. 2). This is the case for widespread race albiventris. There are 4 additional races from NW Argentina (!), at least for tucumanus the same song has been recorded.

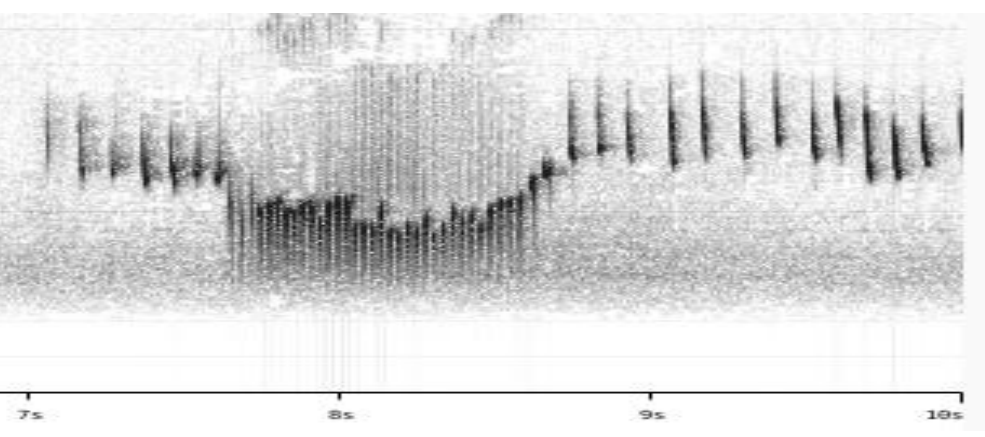

Figure 2: typical song of Cream-winged Cinclodes group

Main features:

max freq of start and end notes: $\quad 8000-10000 \mathrm{~Hz}$

note length in trill: $\quad 0.018-0.019 \mathrm{~s}$

pace in trill: $\quad 0.024-0.03$

max freq of notes in trill: $\quad 5000-6000 \mathrm{~Hz}$

min freq of notes in trill $\quad 2000-2500 \mathrm{~Hz}$

\section{Buff-winged Cinclodes group}

Song is more similar to Chestnut-winged Cinclodes (based on few recordings), but note length shorter and pace faster: a rattling trill initiated with some well-spaced introductory notes and ending with a few rising notes, but overall with little change in pitch. Note shape in trill seems to be somewhat different as well, not nicely overslurred notes (Figure 3).

Compared to Chestnut-winged Cinclodes, there is not a smooth transition from introductory notes into the trill and from the trill into the ending notes (Jaramillo describes this as a trill on same pitch vs a trill going down and up again).

Main features:

note length in trill: $0.018-0.019 \mathrm{~s}$

pace in trill: $0.028-0.03$

max freq of notes in trill: c. $5000 \mathrm{~Hz}$

min freq of notes in trill c. $2000 \mathrm{~Hz}$ 

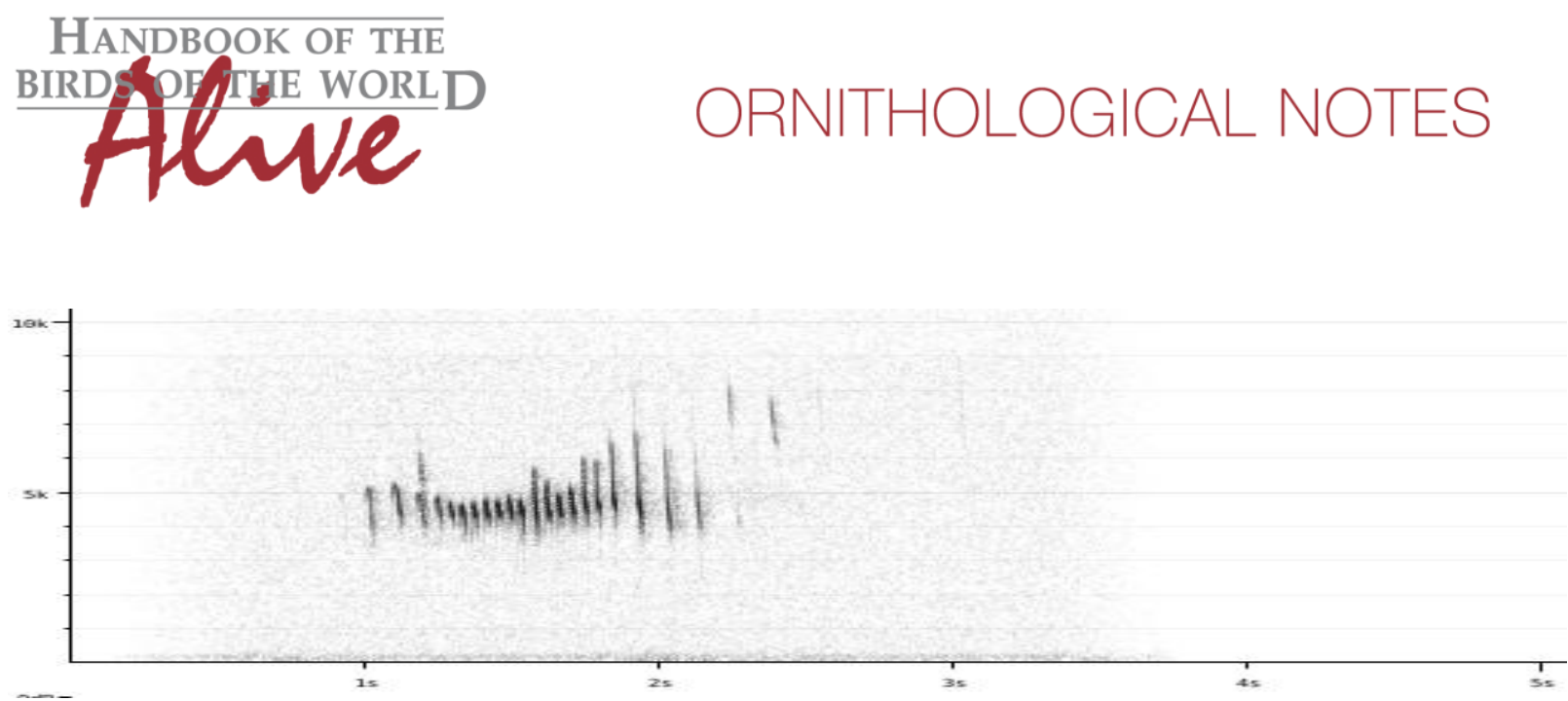

Figure 3: typical song of Buff-winged Cinclodes group

It must be said that depending on the level of excitement, there is quite some variation in song, such as number of notes and total length, and the upper frequency reached.

Song phrases are also sometimes delivered in continuous series. On average, Cream-winged Cinclodes delivers the longest songs with most introductory and ending notes.

We did not compare call notes.

\section{Conclusion:}

Cream-winged Cinclodes group vs. Chestnut-winged Cinclodes group: the former reaches highest frequency and overall largest frequency range (score 3), reaches the highest pace in the trilled part (2) with shortest notes (2). This leads to a total vocal score of 5 when applying Tobias criteria.

Cream-winged Cinclodes group vs. Buff-winged Cinclodes group: the former reaches highest frequency and overall largest frequency range (score 2), has a much larger number of introductory and ending notes (2), and a longer overall song length (1). This leads to a total vocal score of 4 when applying Tobias criteria.

Chestnut-winged Cinclodes group vs. Buff-winged Cinclodes group: the former has the longest note length (score 2), slowest pace (score 2), different note shape (1). This leads to a total vocal score of 4 when applying Tobias criteria.

This note was finalized on 13th July 2015, using sound recordings available on-line at that moment. We would like to thank in particular the many sound recordists who placed their recordings for this species on XC: Israel Aragon, Peter Boesman, Alvaro Jaramillo, Joe Klaiber, Niels Krabbe, Bernabe Lopez-Lanus, John V Moore, Leonardo Ordoñez Delgado, Christian Pinto, John Van der Woude and Charlie Vogt. 


\section{References}

Jaramillo, A. (2003) Birds of Chile. Princeton field guides. New Jersey.

Sanín, C., Cadena, C.D., Maley, J.M., Litjmaer, D.A., Tubaro, P.T. \& Chesser, R.T. (2009)

Paraphyly of Cinclodes fuscus (Aves: Passeriformes: Furnariidae): implications for taxonomy and biogeography. Molecular Phylogenetics and Evolution 53: 547-555.

Tobias, J.A., Seddon, N., Spottiswoode, C.N., Pilgrim, J.D., Fishpool, L.D.C. \& Collar, N.J. (2010). Quantitative criteria for species delimitation. Ibis 152(4): 724-746.

\section{Recommended citation}

Boesman, P. (2016). Notes on the vocalizations of Bar-winged Cinclodes (Cinclodes fuscus). HBW Alive Ornithological Note 89. In: Handbook of the Birds of the World Alive. Lynx Edicions, Barcelona. (retrieved from http://www.hbw.com/node/931984 on 18 July 2016). 